\title{
The Invasion Ecology of Sleeper Populations: Prevalence, Persistence, and Abrupt Shifts
}

MICHAEL J. SPEAR, JAKE R. WALSH, ANTHONY RICCIARDI, AND M. JAKE VANDER ZANDEN

It is well established that nonnative species are a key driver of global environmental change, but much less is known about the underlying drivers of nonnative species outbreaks themselves. In the present article, we explore the concept and implications of nonnative sleeper populations in invasion dynamics. Such populations persist at low abundance for years or even decades-a period during which they often go undetected and have negligible impact-until they are triggered by an environmental factor to become highly abundant and disruptive. Population irruptions are commonly misinterpreted as a recent arrival of the nonnative species, but sleeper populations belie a more complex history of inconspicuous occurrence followed by an abrupt shift in abundance and ecological impact. In the present article, we identify mechanisms that can trigger their irruption, and the implications for invasive species risk assessment and management.

Keywords: invasive species, sleeper populations, persistence, abrupt shifts

$\mathbf{O}^{\text {n }}$ a class field trip in September of 2009, a group of University of Wisconsin-Madison undergraduate limnology students pulled a zooplankton net through the waters of Lake Mendota, continuing a century-long tradition of hands-on learning by sampling the "most studied lake in the world" (Brock 1985). On this trip, their net yielded a new discovery: The sample was teeming with hundreds of a nonnative zooplankter, spiny water flea (Bythotrephes longima$n u s)$. This was the first record of this species in the lake, but its density reflected a lake-wide population of billions. The extreme abundance was particularly surprising because zooplankton in Lake Mendota are monitored regularly by the North Temperate Lakes program (NTL-LTER), part of the US Long Term Ecological Research Network, which had not reported any spiny water flea in the lake to date.

The invasion of the spiny water flea in Lake Mendota would go on to cause significant ecological and economic impacts (Walsh et al. 2016a, 2017), but its sudden outbreaklevel discovery evoked a broader question about the trajectory of this population prior to its detection: How long had the species been in Lake Mendota? Its sudden appearance at high abundance in a well-monitored lake at first suggested the species had only recently arrived and, finding suitable environmental conditions, quickly irrupted. However, subsequent analysis of lake sediment cores and museum samples revealed that the spiny water flea had likely persisted in this lake at low abundances for at least a decade prior to its discovery (figure 1; Walsh et al. 2016b). The small population had evaded as many as 200 NTL-LTER zooplankton sampling events (Walsh et al. 2018). Modeling and empirical studies indicated that the low-abundance population was established but remained undetected until an anomalous cold summer triggered an outbreak, allowing spiny water fleas to reach an exceptionally high abundance (Walsh et al. 2016b).

Although it is a specific example, the case of the spiny water flea in Lake Mendota illustrates the concept and the possible implications of sleeper populations. We define a sleeper population as an established (i.e., reproducing and self-sustaining) nonnative population that persists at low abundance and has innocuous or undetectable impacts but that has the potential to become invasive when triggered by an environmental factor. To help the reader navigate the ecological concepts of the present article without struggling with the often inconsistent terminology of invasion biology (Colautti and MacIsaac 2004) we have included a glossary of terms and definitions in table 1 . The term invasive deserves special attention because it can be applied at multiple scales. Invasive generally describes nonnative organisms that become highly abundant and cause significant (often negative) ecological impacts (Lockwood et al. 2007). This definition most directly applies at the population scale. In other words, as an organism reaches high population abundance and impact, that population of that organism is

BioScience 71: 357-369. (C) The Author(s) 2021. Published by Oxford University Press on behalf of the American Institute of Biological Sciences. 


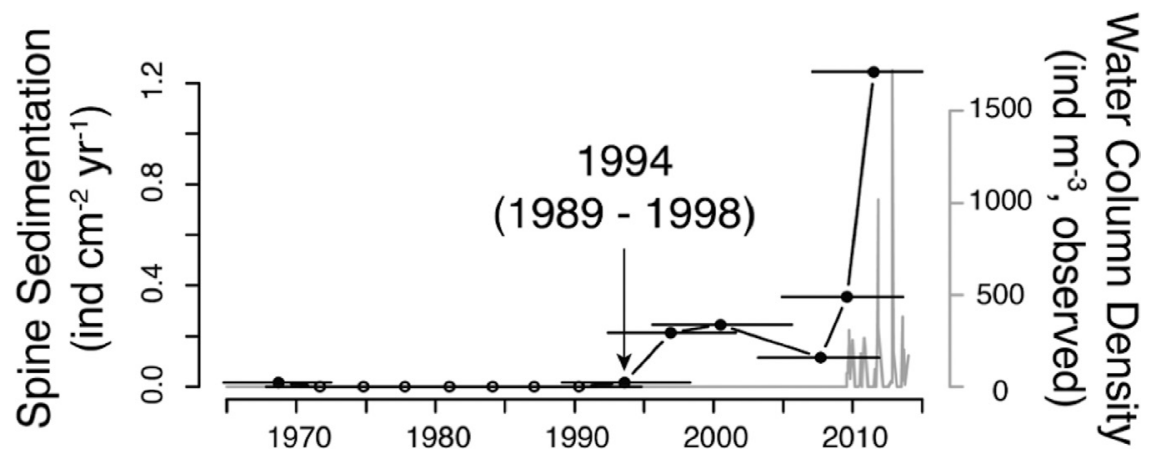

Figure 1. Analysis of a sediment core revealed consistent sedimentation of spines from the invasive spiny water flea (the black line) over a decade before the species was detected by nets in the water column (the gray line) of Lake Mendota (Wisconsin, United States). Adapted from Walsh et al. $2016 \mathrm{~b}$. widely invasive but that these species may become widely invasive with future environmental change. These have been referred to as sleeper species (Groves 1999, 2006, Grice and Ainsworth 2003, Hulme 2017, Bradley et al. 2018, Frank and Just 2020). We note that with the sleeper species concept, the label sleeper is applied at the species scale, not the population scale. In other words, the fates of the established populations of that nonnative species are tied together; they remain at low levels or they outbreak together as a species. In contrast, we apply the sleeper population concept at the population scale, emphasizing that where outbreaks occur depends not only on the species,

deemed invasive. However, if a particular species exhibits many invasive populations across its nonnative range-for example, zebra mussels (Dreissena polymorpha) or gypsy moth (Lymantria dispar)-scientists and managers may describe that species as an "invasive species," thereby applying the term at the species scale.

In the present article, we review and explore the capacity for a population of a nonnative species to establish and persist at low levels in an ecosystem, either at low abundance or in a very localized subhabitat of the larger ecosystem. In either case, these populations often go undetected or are assumed to play a limited role in their receiving ecosystem. Despite their initially small population size, sleeper populations can have great ecological significance if a disturbance or environmental change triggers an outbreak (i.e., an abrupt shift from low to high abundance) causing the population to become invasive.

When a population outbreak of a nonnative species occurs in an ecosystem, it is generally assumed that the species was recently introduced there, when in fact, the events leading up to such an outbreak are unknown. The possibility that a low-abundance population had long been present and simply responded to an opportunity for population growth is not widely considered. Moreover, because these dynamics often play out below detection thresholds, they can be exceptionally difficult to study. But given the accelerating spread of nonnative species (Seebens et al. 2017), combined with the potential for increasing anthropogenic disturbance and directional environmental change (Ratajczak et al. 2018) to trigger outbreaks, we argue that it is critically important to know whether a local outbreak is the result of a recent introduction or of a long-established sleeper population that was triggered by some environmental factor. A better understanding of these early stage dynamics can inform risk assessment, as well as guide optimal strategies for invasive species management.

In the present article, we briefly review several concepts that are related to sleeper populations. It has been proposed that some nonnative species are established but not but also the unique conditions of each ecosystem in which a sleeper population persists. Furthermore, by its definition the sleeper species concept excludes species that are already widely considered invasive at the species scale (i.e., invasive species; Groves 1999, 2006, Grice and Ainsworth 2003, Hulme 2017, Bradley et al. 2018, Frank and Just 2020). This may be an unnecessary limitation, as the example from Lake Mendota highlights a highly invasive species (Yan et al. 2011), spiny water flea, persisting as a sleeper population for many years before an environmental change triggered an outbreak. A fundamental knowledge gap is to what extent low-abundance populations of nonnative species are already established and persisting in sites or ecosystems across the landscape. Where low-abundance populations are prevalent and where these populations go unnoticed, it means that nonnative species are more geographically widespread than currently believed.

Another related and relevant concept is that of time lags in biological invasions (Crooks and Soule 1999, Mack et al. 2000, Crooks 2005, Taylor and Hastings 2005). Time lags have generally referred to the many cases in which a population is slow to reach the high, impactful abundance associated with invasion. For example, an inherent lag refers to the early phase of exponential or logistic growth during which small starting population size keeps density-dependent growth low (Crooks 2005). Populations undergoing inherent lag do not require an environmental trigger prior to the onset of more conspicuous or abrupt growth. In contrast, a sleeper population would otherwise persist indefinitely at low or inconspicuous abundance and impact until triggered by an environmental change. Therefore, sleeper populations are inherently less predictable than those with inherent lags associated with exponential or logistic growth. Crooks (2005) also described a "prolonged lag," which refers to "unexpected" slow growth behavior outside of the "expected" mechanisms of inherent lags. Prolonged lags may go on for years before some eventual change in an ecological factor related to the nonnative population or its new environment leads to an increase in population growth rates 
Table 1. Glossary defining our usage of invasion biology terms in this article along with the literature sources from which we have adopted or adapted these definitions.

\begin{tabular}{lll}
\hline Term & Definition & Adopted or adapted from \\
\hline Established & A population that is reproducing and self-sustaining. & Williamson and Fitter 1996 \\
Invasion history & $\begin{array}{l}\text { A species's history of spread, abundance, and impact (or lack thereof) } \\
\text { in populations outside of its native range. }\end{array}$ & Kolar and Lodge 2001, Kulhanek et al. 2011 \\
Invasive & Reaching high population abundance and impact. & Lockwood et al. 2007 \\
Nonnative & $\begin{array}{l}\text { A species that has been moved outside of its normal geographic range, } \\
\text { regardless of its abundance or impact on native ecosystems. }\end{array}$ & Lockwood et al. 2007 \\
Sleeper population & $\begin{array}{l}\text { An established population of a nonnative species that persists at } \\
\text { low abundance and impact and which has the potential to become } \\
\text { invasive (outbreak to high abundance and impact) if triggered by an } \\
\text { environmental factor. }\end{array}$ & The present article \\
A nonnative species whose populations are established but not yet \\
widely invasive because they are limited by biotic or abiotic conditions.
\end{tabular}

and subsequent outbreak. Crooks recognized the broader implications of prolonged lags: that all established populations of nonnative species-even those with years of lowabundance persistence-carry the potential to irrupt. As a result, Crooks advocated for this precautionary principle to guide the management of biological invasions (2005).

Invasion lags (Crooks and Soule 1999, Crooks 2005) represent a foundational concept that informs much of our treatment of sleeper populations. However, our emphasis is different in that we examine basic principles of population ecology that suggest nonnative species populations are more geographically widespread than is currently known, although at low levels. Often, these low-abundance populations have no measurable impact and are rarely noticed. Nevertheless, they are present in the system and ready to respond if and when suitable conditions present themselves.

Many aspects of the sleeper population phenomenon are not well understood, and there is a need for conceptual synthesis, especially given the potential implications for invasive species management. To evaluate the concept and implications of sleeper populations, we explore three themes. First, we evaluate the phenomenon of nonnative species persisting at low levels. Second, we consider the factors that could cause a low abundance population of a nonnative species to undergo an abrupt shift and reach high abundance. Finally, we consider the potential implications of the sleeper population concept for our understanding, risk assessment, and management of nonnative species in a rapidly changing world. Much of invasion biology emphasizes the role of nonnative species as a driver of environmental change-how species invasions affect biodiversity, ecosystem services, and human well-being (Shackleton et al. 2018). Our review has a different emphasis in that we focus on the underlying drivers of species outbreaks themselves, rather than their consequences.

\section{Persistence of nonnative species populations at low abundance}

There is a widely held view that the small fraction of imported species whose populations become established and grow to high abundance and impact (i.e., invasive species) are endowed with a unique ability to spread, reach high abundance, and exert adverse effects on native species and ecosystems (Hansen et al. 2013). This view underpins the species-scale, trait-based approach to predicting which species are likely to become invasive (Kolar and Lodge 2001, 2002, Keller and Drake 2009). Given this, the idea that a notorious invasive species-for example, the zebra mussel (Dreissena polymorpha) - would establish at a site and persist at low abundance is potentially counterintuitive. On the other hand, a significant body of ecological theory and extensive empirical evidence indicates that species occur as low abundance populations most of the time. It is possible that this principle also applies to those nonnative species with an extensive invasion history, partially resolving this apparent contradiction.

A classic finding in ecology is that the frequency distribution of species' population abundances tends to be log normal (i.e., right skewed; figure 2; Fisher et al. 1943, Brown et al. 1995, McGill et al. 2007). In other words, most populations are low abundance, whereas relatively few populations are high abundance. This pattern implies that low-abundance populations are the rule, not the exception. However, demographic stochasticity (i.e., random fluctuation in population size due to chance births and deaths) works against low-abundance persistence by making small populations more susceptible to local extinction (Lande 1988). This paradox can be at least partially explained by adaptive traits that counteract the disadvantages of rarity, particularly regarding challenges to reproductive success (Rabinowitz 1981, Magurran 2009, Vermeij and Grosberg 2018). In addition to being sustained by metapopulation dynamics (i.e., flow of individuals between connected populations; Hanski 1999), species' adaptions for low-abundance persistence include long life spans that provide long or frequent windows of opportunity for successful reproduction (Magurran and Henderson 2011), as well as the combination of both sexes within one individual (i.e., simultaneous hermaphroditism; Vermeij and Grosberg 2018). Moreover, although interspecific associations between abundant species are dominated 


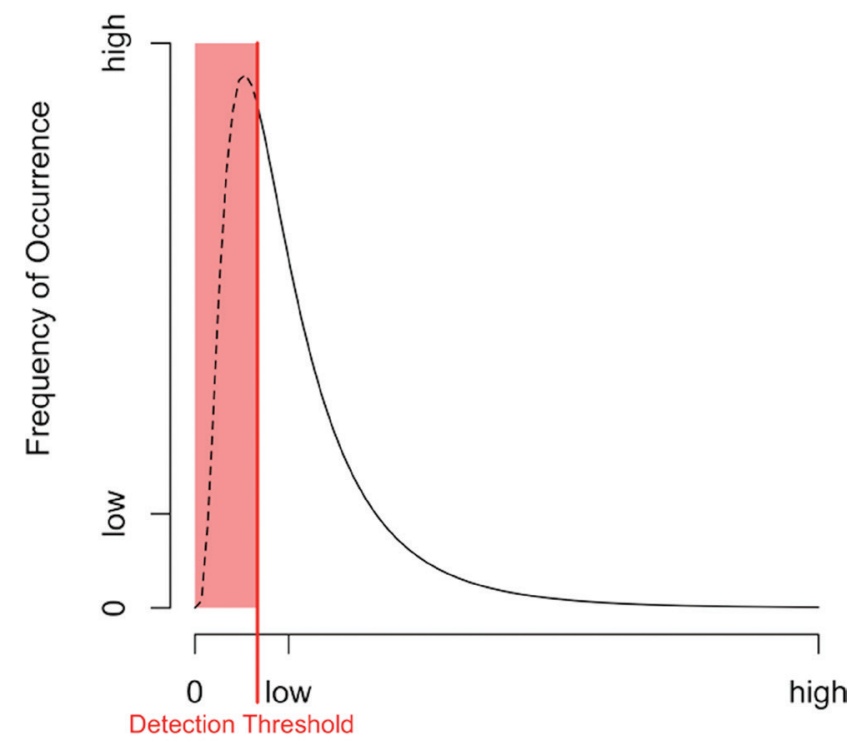

Population Abundance

Figure 2. Hypothetical frequency distribution of population abundances among populations of a given species. As a general rule, most populations of a species occur at low abundance, with relatively few populations occurring at high abundance, creating a right-skewed or log-normal distribution (the black line). Because the probability of detection declines exponentially with decreasing abundance, many low-abundance populations exist below the detection threshold (in red) and go undetected.

by negative interactions such as competition, rare species more often facilitate each other (Calatayud et al. 2020, Hines and Keil 2020), thereby promoting population persistence at low abundance.

Although right-skewed distributions of species abundance are well described for species in general, does this pattern also apply to invasive species? Highly invasive species are known to have certain traits that distinguish them from their less invasive counterparts (Kolar and Lodge 2001, 2002), including the ability to reach high abundance. Therefore, one might expect these species to exhibit a less right-skewed abundance frequency distribution in their nonnative range. Perhaps surprisingly, Hansen and colleagues (2013) found that aquatic species that are considered highly invasive also exhibit highly right-skewed abundance distributions. In fact, frequency distributions of abundance generally resembled those of native species. In other words, it is common for populations to occur and persist at low abundance, even for invasive species.

We must also consider the prevalence of low-abundance populations through the lens of imperfect species detection. The probability of detecting a species on a given sampling event decreases exponentially as population size decreases (Walsh et al. 2018). This problem is illustrated by the classic ecological concept of Preston's veil (Preston 1948). Although we easily observe the most abundant populations of species, low-abundance populations are obscured by a detection threshold or veil (figure 2). Low-abundance populations can be unveiled by increased sampling effort, but most effort is not intense enough to reveal all species that occur at a site. As a result, many low-abundance populations tend to go undetected. Because native and nonnative species both show right-skewed abundance distributions (Hansen et al. 2013), many populations of nonnative species also go undetected, even when dedicated monitoring is in place (Walsh et al. 2018). Furthermore, we often infer the overall distribution of a nonnative species from a collection of local detection efforts by research and management projects of varying quality (Vander Zanden et al. 2017). These challenges of observing low abundance populations suggest that nonnative species could be far more widespread than existing occurrence records would indicate.

The difficulty in even detecting populations at low abundance fundamentally limits our understanding of lowabundance persistence of nonnatives. Fortunately, recent advancements in detection methods such as environmental DNA (eDNA) sampling could improve our ability to detect low-abundance populations (Dejean et al. 2012, Takahara et al. 2013), thereby lifting Preston's veil. For example, eDNA surveys detected a low-abundance population of nonnative Asian carp in a metropolitan Chicago waterway in less than a single person-day of effort, whereas it took traditional electrofishing surveys 93 person-days to yield a detection (Jerde et al. 2011). Although not a panacea, as molecular approaches continue to be developed and improved, they will help us better understand the limits of traditional sampling, and also yield new insights into the geographic distribution of nonnative populations.

The challenges of detecting populations at low abundance not only lead to the underestimation of nonnative species distributions, but they also obscure our understanding of their ecology. For example, at low population levels biologists and natural resource managers have difficulty studying phenomena such as depensation or Allee effects (i.e., smaller populations exhibiting decreased per capita growth rates; Taylor and Hastings 2005, Jensen et al. 2012). Understanding a population's dynamics during the early stages of invasion (introduction, establishment, and subsequent population growth) is critical to understanding how and why it goes extinct, persists, or irrupts, but becomes exceedingly difficult when we cannot observe its individuals.

The inherent challenges of detection also cloud the interpretation of the trajectory of nonnative populations even when we do detect such populations. For example, although we readily notice nonnative populations when they are at high abundance, we are often unable to distinguish among the possible scenarios that preceded the high-abundance state (figure 3). Did an outbreak occur immediately following a new establishment (figure 3a)? Or was there a longsimmering sleeper population that underwent an abrupt population shift in response to an environmental trigger (figure $3 b$ )? When it comes to nonnative populations, the 
When is the non-native species detected relative to population establishment?

\section{High abundance}

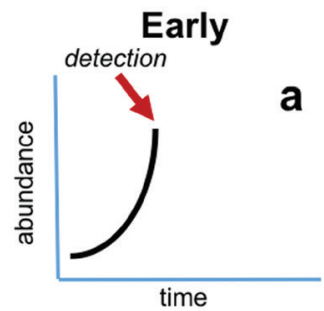

What is the population state when detected?
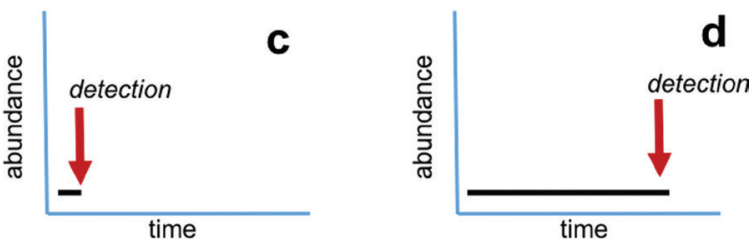

Figure 3. Populations of nonnative species are most often detected when the population reaches high abundance. If a population reaches high abundance soon after its establishment, it may therefore be detected early relative to its establishment (a). Alternatively, a nonnative species population may persist at a low abundance for a prolonged time period between its introduction and its outbreak to high abundance, causing it to be detected late relative to its establishment (b). Although less common, populations of nonnative species can also be detected at low abundance, given sufficient sampling effort or sensitivity. These populations may also be detected (c) soon after establishment (i.e., early) or (d) following prolonged persistence at low abundance (i.e., late).

"absence of evidence is not evidence of absence" (Hawryshyn et al. 2012). Likewise, a new detection does not necessarily indicate that the species has only just arrived. Two freshwater diatom species (Didymosphenia geminata, Stephanodiscus binderanus) illustrate this interpretation conundrum. The sudden emergence of diatom blooms in Canadian lakes was originally interpreted as new introductions of these two species to North America. However, paleolimnological analysis revealed that these species had long been present at low abundance prior to the outbreaks (Hawryshyn et al. 2012, Lavery et al. 2014, Taylor and Bothwell 2014). In this case, it seems likely that environmental change-perhaps changes in nutrient levels or climate-triggered low abundance populations to irrupt.

Occasionally, we do detect a nonnative population at low abundance, although these detections are also difficult to interpret. We are often unable to distinguish between an early detection of a newly established population (figure 3c), a detection of a long-established and persistent low-abundance (i.e., sleeper) population (figure $3 \mathrm{~d}$ ), or a detection event in which newly introduced but as of yet unestablished propagules are detected. In California (United States), repeated, localized detections of nonnative medflies (Ceratitis capitata, Bactrocera dorsalis, Anastrepha ludens) were thought to be coincident with multiple independent introductions (Carey 1996b). Emergency eradication efforts suppressed the outbreaks to undetectable levels in each case, but repeated outbreaks continued. Furthermore, examination of evidence revealed it was more likely that a low-abundance population had established and persisted for some time (Carey 1996a, Papadopoulos et al. 2013). The repeated medfly detections were the result of repeated outbreaks from a sleeper population rather than new, independent introductions.

Although we have considered examples of a nonnative species persisting at low abundance, a related example is a nonnative species becoming established in a highly localized subhabitat, such as a human-disturbed portion of a larger ecosystem. The species could be locally abundant, whereas overall (system-wide) abundance is still low. An example is the recent establishment of several nonnative warm-water fishes (Micropterus salmoides, Lepomis macrochirus, Cyprinus carpio) in shallow marina habitats of Lake Tahoe (California-Nevada, United States; Kamerath et al. 2008). These shallow and highly altered habitats are warm enough to support populations of nonnative warm-water fishes, giving them a permanent foothold in the larger cold-water ecosystem of Lake Tahoe. With Lake Tahoe undergoing rapid warming because of climate change (Coats et al. 2006), these warmwater sleeper populations are poised to colonize Lake Tahoe proper if and when lake-wide conditions become suitable.

There are many examples in which one or a few individuals of nonnative species are detected at a site in isolation. Freshwater examples include a single bloody red shrimp (Hemimysis anomala) that was discovered in DuluthSuperior harbor (Minnesota, United States) in 2017, representing the first detection of this nonnative species in Lake Superior (Myers 2018). Three individual spiny water fleas (Bythotrephes longimanus) were found in the Fox River (Wisconsin, United States) over multiple sampling efforts in recent years (De Stasio and Merkle 2017). A handful of Daphnia lumholtzi were discovered in Navigation Pool 8 of the Mississippi River (Minnesota-Wisconsin, United States) in a recent sampling event (US Fish and Wildlife Service 2018). There are many other examples involving isolated detection at low abundance. Such cases often confound field biologists. What inferences can be made from these observations? Are such records evidence of an established low-abundance population or, rather, aberrant or stray individuals (i.e., unsuccessful invasions)? Although it is 
commonly assumed that these individuals are aberrant and not evidence for established populations, these observations may indicate the presence of sleeper populations.

It seems that nonnative species are capable of persisting at low abundance and that, just as for native species, low abundance populations of nonnative species may be the rule rather than the exception, even for invasive species. Although sleeper populations are not defined by our inability to detect them, the difficulty of detecting low abundance populations limits our understanding of how prevalent sleeper populations might be. Furthermore, the challenges of interpreting low-abundance detections as recent arrivals or established populations confounds our understanding of the persistence and outbreak of low-abundance populations. Improvements in detection and interpretation of low-abundance nonnative species populations will help determine the importance of the sleeper population phenomenon for invasion biology.

\section{Factors that can trigger abrupt shifts}

Although a low-abundance population of a nonnative species is unlikely to have notable impacts (Jackson et al. 2015), an established low-abundance population may be triggered by disturbance or environmental change to undergo irruption. If low-abundance nonnative populations are widespread, considering that ecosystems are increasingly subject to environmental disturbance or environmental change, then the risk of triggered outbreaks may be ubiquitous. Below, we discuss and review some of the possible factors that can cause a sleeper population to undergo an abrupt shift from low to high abundance. An extensive list of examples of sleeper population irruptions can be found in table 2 .

Food web change. There is strong evidence that food web alterations can trigger the irruption of a sleeper population. As an example, introduced cats were present for 60 years on Macquarie Island (Subantarctic Australia), during which time they had a relatively minor impact on native endemic birds. A subsequent introduction of rabbits provided a new food resource that bolstered the cat population, thereby increasing cat predation on the island's birds and leading to the extirpation of two native bird species (Courchamp et al. 1999, 2000, 2003). On Santa Cruz Island (California, United States), disturbance from introduced livestock grazing allowed nonnative fennel (Foeniculum vulgare) patches to establish, although they persisted at low abundance. However, removal of livestock grazers over 100 years later allowed fennel to shift from a low- to high-abundance population that now crowds out native vegetation on the island, triggered by a reversal of the same food web alteration that facilitated its establishment a century prior (Beatty and Licari 1992, Dash and Gliessman 1994).

Completion of a mutualism. Simberloff and von Holle (1999) warned that completion of a once-lost mutualism could trigger outbreaks of low-abundance nonnative populations:
"When a coevolved plant is introduced into an area, it may become a virtual time bomb, requiring only the arrival of the associated insect to set off an invasion." The lack of a mutualist in the introduced range can limit the growth or spread of a nonnative species (Richardson et al. 2000, Mooney and Cleland 2001, Low 2002, Grice and Ainsworth 2003), but reuniting a mutualist pair could trigger the proliferation of both species. For example, nonnative fig trees (Ficus altissima, Ficus benghalensis, and Ficus microcarpa) established in Florida (United States) lacked their coevolved pollinator and were ignored by native fig wasps. Decades later, the introduction of the natural partner wasps allowed the low-abundance fig trees to reproduce and spread, producing impacts on native trees (Nadel et al. 1992, Richardson et al. 2000). The decoupling of mutualisms when a species is imported could explain why some mutualist taxa are underrepresented among highly invasive species, as is the case with legumes, which rely on strong microbial mutualisms (Parker 2001).

Threshold responses. The trigger that causes a sleeper population to irrupt does not need to be a sudden disturbance or perturbation. A gradual change in a driver such as climate can lead to an abrupt shift in the abundance of a population if the system is governed by nonlinear or threshold responses (Ratajczak et al. 2018). Threshold responses have been widely implicated in regime shifts and other abrupt ecological changes (May 1977, Scheffer and Carpenter 2003, Carpenter et al. 2014). For example, climate warming appears responsible for outbreaks of long-established house mouse (Mus musculus) populations on Subantarctic islands. Introduced centuries ago, the mouse populations' reproductive output (a combined measure of fecundity and survival) increased exponentially as temperatures rose (Ferreira et al. 2006). The newly abundant mouse populations now attack native seabird nests, preying on eggs and chicks (Dilley et al. 2016).

Threshold responses have been documented for plants as well. Common cordgrass (Spartina anglica) became highly abundant along the shores of islands in the southern Wadden Sea (Germany) soon after the species's introduction. However, in the cooler waters of the northern Wadden Sea, the common cordgrass population on the Island of Sylt remained low for many years. Loebl and colleagues (2006) posit that as gradual warming of the Wadden Sea raised mean water temperatures past critical physiological thresholds for cordgrass germination (4 degrees Celsius) and photosynthesis (7 degrees Celsius) in the spring, the population achieved higher growth around 15 years after its introduction.

Stochastic environmental driver. Stochastic variation in a limiting environmental driver can provide a window of opportunity for an established low-abundance population of a nonnative species to irrupt. The Bythotrephes longimanus invasion of Lake Mendota described at the beginning of the 
Table 2. Examples of sleeper populations from the literature organized by category of the environmental trigger that caused an abrupt shift in abundance.

\begin{tabular}{|c|c|c|c|c|c|}
\hline Trigger category & Species & Region & Trigger & Impact & Citation \\
\hline \multirow[t]{4}{*}{ Food web change } & $\begin{array}{l}\text { Cat } \\
\text { (Felis catus) }\end{array}$ & $\begin{array}{l}\text { Macquerie Island, } \\
\text { Tasmania, Australia }\end{array}$ & $\begin{array}{l}\text { Introduction of rabbits as } \\
\text { supplementary food resource }\end{array}$ & Extirpated native birds & $\begin{array}{l}\text { Courchamp } \\
\text { et al. } 1999, \\
2000,2003\end{array}$ \\
\hline & $\begin{array}{l}\text { Vine (Operculina } \\
\text { verticosa) }\end{array}$ & $\begin{array}{l}\text { Sarigan Island, } \\
\text { Northern Mariana } \\
\text { Islands }\end{array}$ & $\begin{array}{l}\text { Removal of herbivorous goats } \\
\text { and pigs }\end{array}$ & $\begin{array}{l}\text { Dominates native plant } \\
\text { biomass, carpeting } \\
\text { portions of the island }\end{array}$ & Kessler 2001 \\
\hline & $\begin{array}{l}\text { Crazy ant } \\
\text { (Anoplolepis longipes) }\end{array}$ & $\begin{array}{l}\text { Bird Island, } \\
\text { Seychelles }\end{array}$ & Eradication of predatory rats & $\begin{array}{l}\text { Death of trees, crabs, } \\
\text { birds, and endemic } \\
\text { skink }\end{array}$ & Feare 1999 \\
\hline & $\begin{array}{l}\text { Fennel } \\
\text { (Foeniculum vulgare) }\end{array}$ & $\begin{array}{l}\text { Santa Cruz Island, } \\
\text { California, USA }\end{array}$ & Removal of grazing livestock & $\begin{array}{l}\text { Crowds out native } \\
\text { vegetation }\end{array}$ & $\begin{array}{l}\text { Beatty and Licari } \\
\text { 1992, Dash and } \\
\text { Gliessman } 1994\end{array}$ \\
\hline \multirow[t]{7}{*}{$\begin{array}{l}\text { Completed } \\
\text { mutualism }\end{array}$} & $\begin{array}{l}\text { Fig trees } \\
\text { (Ficus altissima, } F \text {. } \\
\text { benghalensis, and F. } \\
\text { microcarpa) }\end{array}$ & Florida, USA & $\begin{array}{l}\text { Introduction of co-evolved } \\
\text { wasp pollinator }\end{array}$ & Strangles native trees & $\begin{array}{l}\text { Nadel et al. } \\
\text { 1992, Richardson } \\
\text { et al. } 2000\end{array}$ \\
\hline & $\begin{array}{l}\text { Yellow bush lupine } \\
\text { (Lupinus arboreus) }\end{array}$ & Tasmania, Australia & $\begin{array}{l}\text { Introduction of non-native } \\
\text { bumblebee pollinators }\end{array}$ & $\begin{array}{l}\text { Threatens dune } \\
\text { systems }\end{array}$ & Stout et al. 2002 \\
\hline & $\begin{array}{l}\text { Scotch broom } \\
\text { (Cytisus scoparius) }\end{array}$ & $\begin{array}{l}\text { Australia (modeled } \\
\text { scenario) }\end{array}$ & $\begin{array}{l}\text { Introduction of non-native } \\
\text { bumblebee pollinator }\end{array}$ & $\begin{array}{l}\text { Impact was not } \\
\text { modeled }\end{array}$ & $\begin{array}{l}\text { Stokes et al. } \\
2006\end{array}$ \\
\hline & $\begin{array}{l}\text { Black sage } \\
\text { (Cordia interrupta) }\end{array}$ & $\begin{array}{l}\text { Mascarene Islands, } \\
\text { Mauritius }\end{array}$ & $\begin{array}{l}\text { Introduction of seed- } \\
\text { dispersing bird }\end{array}$ & $\begin{array}{l}\text { Crowds out native } \\
\text { vegetation }\end{array}$ & $\begin{array}{l}\text { Cheke 1987, } \\
\text { Vaughan and } \\
\text { Wiehe } 1939\end{array}$ \\
\hline & $\begin{array}{l}\text { Pine trees } \\
\text { (Pseudotsuga menziesii, } \\
\text { Pinus contorta, Pinus } \\
\text { ponderosa) }\end{array}$ & $\begin{array}{l}\text { Isla Victoria, } \\
\text { Argentina }\end{array}$ & $\begin{array}{l}\text { Introduction of ectomycorrhizal } \\
\text { fungi for nitrogen fixation }\end{array}$ & $\begin{array}{l}\text { Dominates native plant } \\
\text { biomass }\end{array}$ & $\begin{array}{l}\text { Nunez et al. } \\
2009\end{array}$ \\
\hline & $\begin{array}{l}\text { Unspecified legume } \\
\text { spp. }\end{array}$ & $\begin{array}{l}\text { Modeled interaction, } \\
\text { no specific region }\end{array}$ & $\begin{array}{l}\text { Introduction of co-evolved } \\
\text { rhizobia bacteria for nitrogen } \\
\text { fixation }\end{array}$ & $\begin{array}{l}\text { Impact was not } \\
\text { modeled }\end{array}$ & Parker 2001 \\
\hline & $\begin{array}{l}\text { Acacia trees } \\
\text { (Acacia longifolia, Acacia } \\
\text { melanoxylon) }\end{array}$ & Portugal & $\begin{array}{l}\text { Introduction of co-evolved } \\
\text { rhizobia bacteria for nitrogen } \\
\text { fixation }\end{array}$ & $\begin{array}{l}\text { Crowds out native } \\
\text { vegetation }\end{array}$ & $\begin{array}{l}\text { Rodríguez- } \\
\text { Echeverría et al. } \\
2012\end{array}$ \\
\hline \multirow[t]{8}{*}{$\begin{array}{l}\text { Threshold } \\
\text { response }\end{array}$} & $\begin{array}{l}\text { Common cordgrass } \\
\text { (Spartina anglica) }\end{array}$ & $\begin{array}{l}\text { Island of Sylt, } \\
\text { Germany }\end{array}$ & $\begin{array}{l}\text { Warming climate crossed } \\
\text { temperature thresholds } \\
\text { for germination and } \\
\text { photosynthesis }\end{array}$ & $\begin{array}{l}\text { Crowds out native } \\
\text { vegetation }\end{array}$ & Loebl et al. 2006 \\
\hline & $\begin{array}{l}\text { Pacific oyster } \\
\text { (Crassostrea gigas) and } \\
\text { barnacle (Austrominius } \\
\text { modestus) }\end{array}$ & $\begin{array}{l}\text { Island of Sylt, } \\
\text { Germany }\end{array}$ & $\begin{array}{l}\text { Warming summer } \\
\text { temperatures crossed } \\
\text { thresholds for recruitment }\end{array}$ & $\begin{array}{l}\text { Displaces native } \\
\text { mussels and barnacles }\end{array}$ & $\begin{array}{l}\text { Diederich et al. } \\
\text { 2005, Büttger } \\
\text { et al. 2008, } \\
\text { Witte et al. } 2010\end{array}$ \\
\hline & $\begin{array}{l}\text { Slipper limpet } \\
\text { (Crepidula fornicata) }\end{array}$ & $\begin{array}{l}\text { Island of Sylt, } \\
\text { Germany }\end{array}$ & $\begin{array}{l}\text { Milder winters no longer dip } \\
\text { below mortality temperature } \\
\text { thresholds }\end{array}$ & $\begin{array}{l}\text { Possibly competes } \\
\text { with native mussels }\end{array}$ & Nehls et al. 2006 \\
\hline & $\begin{array}{l}\text { Epiphytic bryozoan } \\
\text { (Membranipora } \\
\text { membranacea) }\end{array}$ & $\begin{array}{l}\text { Western North } \\
\text { Atlantic Ocean }\end{array}$ & $\begin{array}{l}\text { Warming temperatures trigger } \\
\text { nonlinear growth response }\end{array}$ & $\begin{array}{l}\text { Defoliates kelp forests, } \\
\text { facilitating non-native } \\
\text { algae }\end{array}$ & $\begin{array}{l}\text { Saunders et al. } \\
2010\end{array}$ \\
\hline & $\begin{array}{l}\text { House mouse } \\
\text { (Mus musculus) }\end{array}$ & Subantarctic islands & $\begin{array}{l}\text { Warming climate crossed } \\
\text { reproductive temperature } \\
\text { thresholds }\end{array}$ & $\begin{array}{l}\text { Preys on native seabird } \\
\text { eggs and chicks }\end{array}$ & $\begin{array}{l}\text { Ferreira et al. } \\
2006 \text {, Dilley } \\
\text { et al. } 2016\end{array}$ \\
\hline & $\begin{array}{l}\text { Freshwater diatom } \\
\text { (Didymosphenia } \\
\text { geminate) }\end{array}$ & $\begin{array}{l}\text { Quebec, Canada and } \\
\text { other rivers globally }\end{array}$ & $\begin{array}{l}\text { Climate warming and/or } \\
\text { phosphorus reduction coincide } \\
\text { with large blooms }\end{array}$ & $\begin{array}{l}\text { Blooms intensely, } \\
\text { threatening salmonid } \\
\text { fisheries }\end{array}$ & $\begin{array}{l}\text { Lavery et al. } \\
\text { 2014, Taylor and } \\
\text { Bothwell } 2014\end{array}$ \\
\hline & $\begin{array}{l}\text { Freshwater diatom } \\
\text { (Stephanodiscus } \\
\text { binderanus) }\end{array}$ & $\begin{array}{l}\text { Laurentian Great } \\
\text { Lakes region, USA } \\
\text { and Canada }\end{array}$ & $\begin{array}{l}\text { Long-term fluctuations in } \\
\text { nutrients coincide with } \\
\text { emergence and disappearance } \\
\text { in paleolimnological record }\end{array}$ & $\begin{array}{l}\text { Blooms intensely, } \\
\text { impacting water quality }\end{array}$ & $\begin{array}{l}\text { Hawryshyn et al. } \\
2012\end{array}$ \\
\hline & $\begin{array}{l}\text { Dermo disease } \\
\text { (Perkinsus marinus) }\end{array}$ & $\begin{array}{l}\text { North Atlantic } \\
\text { Ocean, USA }\end{array}$ & $\begin{array}{l}\text { Milder winters caused } \\
\text { outbreak of dormant oyster } \\
\text { parasite }\end{array}$ & $\begin{array}{l}\text { Parasitizes oyster } \\
\text { populations }\end{array}$ & Ford 1996 \\
\hline \multirow[t]{2}{*}{$\begin{array}{l}\text { Stochastic } \\
\text { environmental } \\
\text { driver }\end{array}$} & $\begin{array}{l}\text { Spiny water flea } \\
\text { (Bythotrephes } \\
\text { longimanus) }\end{array}$ & $\begin{array}{l}\text { Lake Mendota, } \\
\text { Wisconsin, USA }\end{array}$ & $\begin{array}{l}\text { Anomalous mild summer } \\
\text { allowed sexual production of } \\
\text { robust egg bank }\end{array}$ & $\begin{array}{l}\text { Reduces native } \\
\text { zooplankton }\end{array}$ & $\begin{array}{l}\text { Walsh et al. } \\
\text { 2016a, 2016b }\end{array}$ \\
\hline & $\begin{array}{l}\text { St. John's wort } \\
\text { (Hypericum perforatum) }\end{array}$ & $\begin{array}{l}\text { Southeastern } \\
\text { Australia }\end{array}$ & $\begin{array}{l}\text { Anomalous heavy precipitation } \\
\text { allowed germination of a } \\
\text { low-abundance population's } \\
\text { seed bank }\end{array}$ & $\begin{array}{l}\text { Displaces native } \\
\text { vegetation and is toxic } \\
\text { to livestock }\end{array}$ & Briese 1997 \\
\hline
\end{tabular}


The sleeper population concept raises many questions regarding the prevalence of low-abundance populations and their potential to outbreak if triggered by an environmental factor. Below we outline several research questions that could guide the exploration of sleeper populations and their importance for the understanding, risk assessment, and management of biological invasions.

How prevalent are low-abundance populations of nonnative species?

To what extent and by what means can we improve our ability to detect low-abundance populations?

For how long do low-abundance populations of nonnative species tend to persist before local extinction or outbreak?

When we detect nonnative populations at low abundance, how can we distinguish between populations undergoing inherent lags such as the early phases of exponential or logistic growth versus sleeper populations that may persist at low-population levels indeterminately until triggered to outbreak by environmental change?

When we detect nonnative populations at high abundance, how can we distinguish between outbreaks that occurred immediately following establishment versus outbreaks from latent sleeper populations?

What kinds of environmental factors can trigger sleeper population outbreaks? Are certain triggers (e.g., completion of a mutualism, food web change, etc.) more prevalent than others?

Are certain species, species traits, ecosystem types, or biogeographic contexts highly associated with certain environmental triggers, like a lock and key?

Are sleeper populations more common among nonnative species with limited or extensive invasion histories?

Are populations of nonnative species with extensive invasion histories more susceptible to environmental triggers at the edges of their invaded range relative to the core of their invaded range?

present article is one example. This lake was not considered suitable habitat for Bythotrephes, because it is warm and eutrophic and because Bythotrephes are understood to prefer colder, unproductive lakes. Nevertheless, Bythotrephes were detected in Lake Mendota in the fall of 2009, with several lines of evidence suggesting a sleeper population persisted for at least a decade prior to this discovery (Walsh et al. 2016b). A population model used to simulate Bythotrephes population dynamics yielded unique insights into this triggered irruption. In the model, the high summer water temperatures that are typical of Lake Mendota prevented population growth. However, 2009 was an anomalously cold summer. When the Bythotrephes population model was run using 2009 water temperature data, a low-abundance population grew rapidly to high abundance. In the lake, the large egg bank that Bythotrephes produced in 2009 has continued to sustain high population abundance even when thermally unfavorable conditions returned in the following years (Walsh et al. 2016b). Relationships between future summer surface temperatures, lake stratification timing, and trophic interactions will dictate if and when the population might deplete its egg bank and return to low abundance (Walsh et al. 2016b).

Similarly, nonnative plants can establish low-abundance populations in unfavorable conditions, and their long-lived seed banks opportunistically germinate during the occasional windows of environmentally favorable conditions (Briese 1997, Grice and Ainsworth 2003). These examples suggest that ecological changes need not be directional, or even persistent, to trigger a sleeper population to undergo an outbreak. Increasing climatic stochasticity is likely to accompany global climate change (Rahmstorf and Coumou 2011, Field et al. 2012, Vasseur et al. 2014), thereby increasing the likelihood that stochastic environmental drivers could trigger outbreaks of sleeper populations.

Native species can also exhibit high abundance and impact following a triggering disturbance that releases a population from biotic or abiotic constraints (Simberloff et al. 2012). However, this phenomenon is rare, and we speculate that low-abundance nonnative populations are more likely to outbreak than native populations because nonnatives are often introduced to evolutionary and ecological contexts that lack the coevolved constraints of their native range. Furthermore, the processes by which nonnative populations are introduced can select for species able to reproduce from small numbers and that thrive under human disturbance (Wilson et al. 2009, Hufbauer et al. 2012).

\section{Implications for understanding and management of invasive species}

Although it is clear from these examples that sleeper populations can occur and can irrupt, fundamental questions remain (box 1). How prevalent are sleeper populations in nature? To what extent do they explain the appearance of invasive populations on the landscape? Are there certain taxa that tend to exhibit sleeper population dynamics, and others that do not? Are sleeper populations more common in certain types of ecosystems than in others? Addressing 


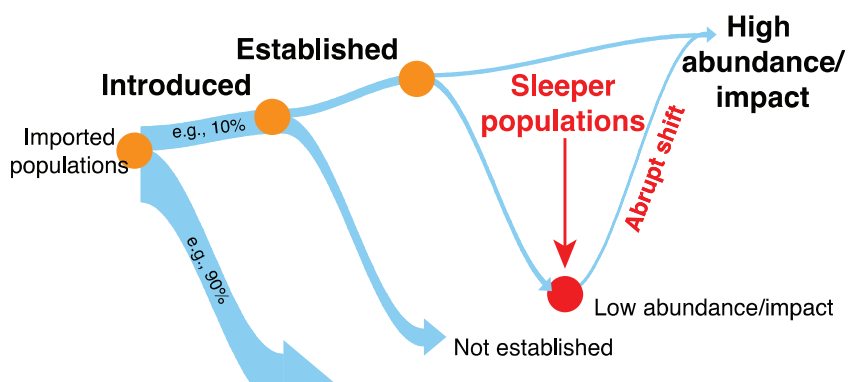

Not introduced

Figure 4. At each step in the invasion process, most imported populations are filtered out by the tens rule, resulting in only a fraction of populations becoming invasive. Lowabundance populations filtered out between established and high abundance or impact often go undetected or are considered benign, but these populations may not be permanently removed from the invasion process. Sleeper populations can persist at low abundance, and abrupt shifts offer a pathway back into the invasion process toward high abundance or impact. The sleeper population concept adds a dynamic temporal component to traditionally static invasion process framework of the tens rule.

these questions has implications for our fundamental understanding of the dynamics of nonnative species, as well as their management.

The possibility of sleeper populations influences how we might best manage biological invasions. As an example, understanding the population dynamics of the medfly (Ceratitis capitata) invasion of California (United States) described earlier had profound implications for how population outbreaks were optimally managed. When repeated, localized outbreaks of medfly were detected, they were assumed to stem from repeated, localized introductions of the nonnative species. In response, international shipping vessel restrictions aimed at preventing new medfly introductions became the focus of invasion management efforts. However, closer analysis of the location and timing of medfly detections revealed a different story-that persistent, low-abundance populations were already established in California and served as the source of the repeated outbreaks. With established sleeper populations as the ultimate source of the outbreaks, it was clear that shipping restrictions aimed at reducing new medfly introductions from abroad was not an effective strategy for managing the species (Carey 1996a, 1996b).

As in the medfly case, many invasive species management efforts aim to prevent invasive populations from spreading to new locations. In an example from lakes, recreational boaters are a major vector for the transport of species such as the nonnative plant Eurasian watermilfoil (Myriophyllum spicatum) from lake to lake (Rothlisberger and Lodge 2011). In response, prevention programs aim at convincing boaters to clean their boats and gear if they are moving from one lake to another. Although preventing boaters from spreading individuals from invaded to uninvaded lakes is sensible and generally a solid invasive species management strategy (Leung et al. 2002, Vander Zanden et al. 2010), the prospect of sleeper populations suggests the need for a broader view than the dominant paradigm of simply preventing spread to uninvaded sites. Although lake management programs strive to prevent boaters from spreading Eurasian watermilfoil to an uninvaded lake, what if Eurasian watermilfoil has already colonized that lake and is persisting as a sleeper population? Limiting new introductions might prevent boaters from kickstarting an abrupt shift of an existing population to high abundance, but the ultimate fate of a potential invasion could lie in environmental triggers that are unrelated to boater behavior.

A critical source of leverage when managing biological invasions is that only a small fraction of populations become invasive (i.e., high abundance and impact), which allows managers to target limited resources to the most harmful populations and vulnerable systems (Vander Zanden and Olden 2008). This filtering process is the basis of the tens rule, which posits that a small proportion (e.g., approximately $10 \%$ ) of potential invaders pass through each filter or step of the invasion process (i.e., introduction, establishment, high abundance or impact; Williamson and Fitter 1996). Although empirical studies have challenged the original conceptual value of $10 \%$ that applies to each filter; it may be as high as $50 \%$ for vertebrates and $25 \%$ for plants and insects (Jeschke and Pišek 2018); it is still generally accepted that only a fraction of imported populations pass through all filters of the invasion process and exhibit the high abundance and impact associated with invasions (Williamson and Fitter 1996, Colautti and MacIsaac 2004). The sleeper population concept adds to this framework by allowing for a dynamic, temporal component. Even if a population is initially filtered out of the invasion process before the final high abundance or impact step, its fate might be altered by some environmental change that triggers a population outbreak (e.g., food web change, completion of a mutualism, etc.). Within a species's nonnative range, sleeper populations are those that are stuck between the establishment and high abundance or impact steps. When detected, these populations may even be labeled benign by resource managers. However, abrupt shifts offer a pathway back toward high abundance or impact status for sleeper populations (figure 4), adding a dynamic component to this traditionally static conceptualization of the invasion process.

\section{Considerations for invasion debt}

The sleeper population concept certainly invokes the idea of invasion debt (Essl et al. 2011, Rouget et al. 2016), an invasion biology tenet that represents the as of yet unrealized impacts of past nonnative species introductions and highlights the value of proactive management that limits introductions and spread. For example, imagine a species that has arrived in and is spreading throughout a region, 
but presently occupies only a small portion of its potential nonnative range. Although widespread invasion impacts have yet to materialize, they will accumulate as the species spreads to new sites. Along these lines, a species with established sleeper populations represents an insidious form of invasion debt, and one that does not require that there be additional transport or spread because the species is already present in ecosystems in which it may cause future impacts. However, the manifestation of sleeper population debt is not inevitable. Rather, it could be mediated by environmental triggers that may or may not be pulled.

Sleeper populations are already present at a site and await suitable conditions or disturbance that would allow their population to irrupt. Like fuel for the fire of future invasions, sleeper populations can ignite if exposed to the sparks of environmental change. With accelerating global environmental change and increasing intensity of ecological disturbance and extreme events (Dale et al. 2001, Trapp et al. 2007, Diffenbaugh and Field 2013), the potential for abrupt shifts in ecosystems is likely increasing (Ratajczak et al. 2018). In many cases, this may apply to nonnative species population outbreaks. At present, we know little about the factors that might trigger a sleeper population to undergo an outbreak, and in many cases the triggers may not be under management control-for example, in the case of climate. Other factors such as water level fluctuations or fire regime are often under direct management control. In such cases, management strategies could be designed specifically to prevent outbreaks of sleeper populations. In any case, we must recognize that the population dynamics of nonnative species often play out in ecosystems subject to rapid environmental change. The accelerating frequency and intensity of that change may be like tossing lit matches toward a volatile stockpile of sleeper populations.

Because the sleeper population concept applies at the population scale, the fate of each invasion is dictated by the unique context of each nonnative species and its biotic and abiotic constraints within a recipient ecosystem. Although many low-abundance populations may have the potential to irrupt, not all populations may share the same environmental triggers. Furthermore, not all environmental triggers may have the same likelihood of occurring. Identifying which nonnative populations have a significant potential to irrupt will be critical for leveraging the sleeper population concept for the management of biological invasions. These sleeper populations should be sought out and defused before some environmental change can trigger their irruption.

\section{Future research directions}

Post hoc analysis of nonnative species population outbreaks can add to the understanding of early stage dynamics of invasions and reveal whether outbreaks are the result of recent introductions or sleeper populations. For example, timelines of invasions can be reconstructed where identifiable and dateable historic evidence exists, such as with subfossils (Mergeay et al. 2006, Hawryshyn et al. 2012, Walsh et al. 2016b), sedimented eDNA (Taylor and Bothwell 2014, Stager et al. 2015, Graham et al. 2016), or museum and herbarium specimens (Provan et al. 2008). Opportunities for post hoc analysis might also come from biocontrol applications. Because introduction is intentional in these cases, we can know with more certainty if a population outbreak coincides with introduction or if some later ecosystem change triggered an abrupt shift.

Improvements in our ability to detect rare species could help determine the prevalence of sleeper populations. For many nonnative species, our understanding of their geographic distributions is surprisingly limited. Many are not systematically surveyed, and for those species that tend to be more high profile, our understanding of their geographic distribution likely reflects locations in which they are abundant and therefore conspicuous (Vander Zanden et al. 2017). Recent advances in molecular approaches to species detection (eDNA) have potential for improving our ability to detect low-level populations (Rees et al. 2014). Other emerging tools for species detection such as citizen science and remote sensing can help expand geographic coverage of nonnative species sampling (Larson et al. 2020). Although long-term monitoring is not always sufficient to detect sleeper populations (Walsh et al. 2016b, 2018), it can improve detection of some rare species over time (Magurran et al. 2010). Establishing the degree to which nonnative species exhibit persistent, low-abundance populations is foundational information and remains poorly understood.

The idea that populations of nonnative species persist at low levels across the landscape may run counter to the general perception of invasions as being explosive with regard to spread, abundance, and impact. But perhaps another feature that contributes to the success of a nonnative species is the ability to persist at low abundance until conditions are suitable for irruption. Imagine propagules of a species colonizing a new ecosystem. Although conditions at the site may be far from optimal, a species adapted for low abundance can still establish and persist. If and when the environment changes, the species is ready to irrupt. Therefore, trait-based predictions of which species may invade the most sites may benefit from considering traits that allow low-abundance persistence, in addition to those that promote rapid growth and spread (Keller and Drake 2009). Furthermore, predictions based on a species's history of invasion (Kolar and Lodge 2001) carry extra uncertainty in light of sleeper population irruptions. A species's invasion history-even one composed of decades of benign, low-abundance establishments-can be quickly rewritten by abrupt shifts, rendering the past a less reliable predictor of future risks (Crooks 2005).

\section{Conclusions}

A growing collection of sleeper population examples (table 2) supports classic ecological theory (Fisher et al. 1943, Brown et al. 1995, McGill et al. 2007) in suggesting that persistent, low-abundance populations of nonnative species may be littered across the landscape. By building on these concepts we 
highlight that sleeper populations may be widespread and may hold significant potential to irrupt with environmental change. In an era defined by accelerating environmental change (Ratajczak et al. 2018), the environmentally triggered irruption of these sleeper populations represents an insidious form of invasion debt. The manifestation of this debt requires no additional transport or spread; the invaders are already present. Incorporating the sleeper population concept into broader thinking and management of nonnative species requires a more inclusive accounting of the invasion debt already accumulated on our landscapes, a more dynamic treatment of the risk associated with low-abundance establishment of nonnative species populations, and a more thoughtful interpretation of the local history of newly discovered nonnative populations. Identifying the extent to which sleeper populations persist across the landscape and the mechanisms by which they are triggered to outbreak has important consequences for the theory, risk assessment, and management of biological invasions.

\section{Acknowledgments}

The authors thank Emily Stanley and Steve Carpenter for their thoughtful comments on the manuscript. This work was supported by the NSF North Temperate Lakes Long Term Ecological Research Program grant no. DEB-1440297, the Wisconsin Department of Natural Resources Surface Waters grant no. MSN193839, the United States Geological Survey Upper Midwest Environmental Sciences Center, and the Wisconsin Cooperative Fishery Research Unit.

\section{References cited}

Beatty SW, Licari DL. 1992. Invasion of fennel (Foeniculum vulgare) into shrub communities on Santa Cruz Island, California. Madrano 54-66.

Boudjelas S, Browne M, De Poorter M, Lowe S. 2000. 100 of the World's Worst Invasive Alien Species: A Selection From the Global Invasive Species Database. International Union for Conservation of Nature.

Bradley B, Beaury E, Fusco E, Laginhas B, Morelli T, Pasquarella V. 2018. Regional invasive species and climate change management challenge: Preparing for sleeper species. Environmental Conservation Education Materials. ScholarWorks @UMassAmherst. (https://doi.org/10.7275/ R5F18WXT),

Briese D. 1997. Population dynamics of St. John's wort in southeastern Australia. Plant Protection Quarterly 12: 59-63.

Brock T. 1985. A Eutrophic Lake: Lake Mendota, Wisconsin. Spring Science, Business Media.

Brown JH, Mehlman DW, Stevens GC. 1995. Spatial variation in abundance. Ecology 76: 2028-2043.

Büttger H, Asmus H, Asmus R, Buschbaum C, Dittmann S, Nehls G. 2008. Community dynamics of intertidal soft-bottom mussel beds over two decades. Helgoland Marine Research 62: 23-36.

Calatayud J, et al. 2020. Positive associations among rare species and their persistence in ecological assemblages. Nature Ecology and Evolution 4: 40-45.

Carey JR. 1996a. The future of the mediterranean fruit fly Ceratitis capitata invasion of California: A predictive framework. Biological Conservation 78: $35-50$.

Carey JR. 1996b. The incipient Mediterranean fruit fly population in California: Implications for invasion biology. Ecology 77: 1690-1697.

Carpenter SR, Brock WA, Cole JJ, Pace ML. 2014. A new approach for rapid detection of nearby thresholds in ecosystem time series. Oikos 123: $290-297$.
Cheke AS. 1987. An ecological history of the Mascarene Islands, with particular reference to extinctions and introductions of land vertebrates. Pages 5-89 in Diamond AW, ed. Mascarene Island Birds. Cambridge University Press.

Coats R, Perez-Losada J, Schladow G, Richards R, Goldman C. 2006. The warming of Lake Tahoe. Climatic Change 76: 121-148.

Colautti RI, MacIsaac HI. 2004. A neutral terminology to define "invasive" species. Diversity and Distributions 10: 135-141.

Courchamp F, Chapuis JL, Pascal M. 2003. Mammal invaders on islands: Impact, control, and control impact. Biological Reviews of the Cambridge Philosophical Society 78: 347-383.

Courchamp F, Langlais M, Sugihara G. 1999. Control of rabbits to protect island birds from cat predation. Biological Conservation 89: 219-225.

Courchamp F, Langlais M, Sugihara G. 2000. Rabbits killing birds: Modelling the hyperpredation process. Journal of Animal Ecology 69: 154-164.

Crooks JA. 2005. Lag times and exotic species: The ecology and management of biological invasions in slow-motion. Ecoscience 12: 316-329.

Crooks JA, Soule ME. 1999. Lag times in population explosions of invasive species: Causes and implications. Pages 103-125 in Sandlund OT, Schei PJ, Viken A, eds. Invasive Species and Biodiversity Management. Kluwer Academic Publishers.

Dale VH, et al. 2001. Climate change and forest disturbances: Climate change can affect forests by altering the frequency, intensity, duration, and timing of fire, drought, introduced species, insect and pathogen outbreaks, hurricanes, windstorms, ice storms, or landslides. BioScience 51: 723-734.

Dash B, Gliessman S. 1994. Nonnative species eradication and native species enhancement: Fennel on Santa Cruz Island. Pages 505-512 in Halvorson WL, Maender GL, eds. The Fourth California Islands Symposium: Update On The Status of Resources. Santa Barbara Museum of Natural History.

Dejean T, Valentini A, Miquel C, Taberlet P, Bellemain E, Miaud C. 2012. Improved detection of an alien invasive species through environmental DNA barcoding: The example of the American bullfrog Lithobates catesbeianus. Journal of Applied Ecology 49: 953-959.

De Stasio B, Merkle C. 2017. Spiny water flea (Bythotrephes longimanus) and round goby (Neogobius melanostomus) monitoring in southern Green Bay, Lake Michigan, Lower Fox River, and Lake Winnebago during 2016. Lawrence University Biology Department report.

Diederich S, Nehls G, van Beusekom JE, Reise K. 2005. Introduced Pacific oysters (Crassostrea gigas) in the northern Wadden Sea: Invasion accelerated by warm summers? Helgoland Marine Research 59: 97-106.

Diffenbaugh NS, Field CB. 2013. Changes in ecologically critical terrestrial climate conditions. Science 341: 486-492.

Dilley BJ, Schoombie S, Schoombie J, Ryan PG. 2016. "Scalping" of albatross fledglings by introduced mice spreads rapidly at Marion Island. Antarctic Science 28: 73-80.

Essl F, et al. 2011. Socioeconomic legacy yields an invasion debt. Proceedings of the National Academy of Sciences 108: 203-207.

Feare C. 1999. Ants take over from rats on Bird Island, Seychelles. Bird Conservation International 9: 95-96.

Ferreira SM, Van Aarde RJ, Wassenaar TD. 2006. Demographic responses of house mice to density and temperature on sub-Antarctic Marion Island. Polar Biology 30: 83-94.

Field CB, et al. 2012. Managing the risks of extreme events and disasters to advance climate change adaptation. Special report of the Intergovernmental Panel on Climate Change. Cambridge University Press.

Fisher RA, Corbet AS, Williams CB. 1943. The relation between the number of species and the number of individuals in a random sample of an animal population. Journal of Animal Ecology 12: 42.

Ford S. 1996. Range extension by the oyster parasite Perkinsus marinus into the northeastern United States: Response to climate change? Journal of Shellfish Research 15: 45-56.

Frank SD, Just MG. 2020. Can cities activate sleeper species and predict future forest pests? A case study of scale insects. Insects 11: 142. 
Graham RW, et al. 2016. Timing and causes of mid-Holocene mammoth extinction on St. Paul Island, Alaska. Proceedings of the National Academy of Sciences 113: 9310-9314.

Grice AC, Ainsworth N. 2003. Sleeper weeds: A useful concept? Plant Protection Quarterly 18: 35-39.

Groves RH. 1999. Sleeper Weeds. Pages 632-636 in Bishop AC, Boersma M, Barnes CD, eds. 12th Australian Weeds Conference, Papers and Proceedings. University of Tasmania.

Groves RH. 2006. Are some weeds sleeping? Some concepts and reasons. Euphytica 148: 111-120.

Hansen GJA, et al. 2013. Commonly rare and rarely common: Comparing population abundance of invasive and native aquatic species. PLOS ONE 8: e77415.

Hanski I. 1999. Metapopulation Ecology. Oxford University Press.

Hawryshyn J, Rühland KM, Julius M, Smol JP. 2012. Absence of evidence is not evidence of absence: Is Stephanodiscus binderanus (Bacillariophyceae) an exotic species in the great lakes region? Journal of Phycology 48: 270-274.

Hines J, Keil P. 2020. Common competitors and rare friends. Nature Ecology and Evolution 4: 8-9.

Hufbauer RA, Facon B, Ravigné V, Turgeon J, Foucaud J, Lee CE, Rey O, Estoup A. 2012. Anthropogenically induced adaptation to invade (AIAI): Contemporary adaptation to human-altered habitats within the native range can promote invasions. Evolutionary Applications 5: 89-101.

Hulme PE. 2017. Climate change and biological invasions: Evidence, expectations, and response options. Biological Reviews 92: 1297-1313.

Jackson MC, Ruiz-Navarro A, Britton JR. 2015. Population density modifies the ecological impacts of invasive species. Oikos 124: 880-887.

Jensen OP, Branch TA, Hilborn R. 2012. Marine fisheries as ecological experiments. Theoretical Ecology 5: 3-22.

Jerde CL, Mahon AR, Chadderton WL, Lodge DM. 2011. "Sightunseen" detection of rare aquatic species using environmental DNA. Conservation Letters 4: 150-157.

Jeschke J, Pyšek P. 2018. Tens rule. Pages 124-132 in Jeschke J, Heger T, eds. Invasion Biology Hypothesis and Evidence. Centre for Agriculture and Bioscience International.

Kamerath M, Chandra S, Allen BC. 2008. Distribution and impacts of warm water invasive fish in Lake Tahoe, USA. Aquatic Invasions 3: 35-41.

Keller RP, Drake JM. 2009. Trait-based risk assessment for invasive species. Pages 44-62 in Shogren J, Keller RP, Lodge D, Lewis MA, eds. Bioeconomics of Invasive Species: Integrating Ecology, Economics, Policy, and Management. Oxford University Press.

Kessler CC. 2001. Eradication of feral goats and pigs from Sarigan Island, Commonwealth of the Northern Mariana Islands: Methods and results. Pages 132-140 in Veitch CR, Clout MN, eds. Turning the Tide: The Eradication of Invasive Species. International Union for Conservation of Nature.

Kolar CS, Lodge DM. 2001. Progress in invasion biology: Predicting invaders. Trends in Ecology and Evolution 16: 199-204.

Kolar CS, Lodge DM. 2002. Ecological predictions and risk assessment for alien fishes in North America. Science 298: 1233-1236.

Kulhanek SA, Ricciardi A, Leung B. 2011. Is invasion history a useful tool for predicting the impacts of the world's worst aquatic invasive species? Ecological Applications 21: 189-202.

Lande R. 1988. Genetics and demography in biological conservation. Science 241: 1455-1460.

Larson ER, et al. 2020. From eDNA to citizen science: Emerging tools for the early detection of invasive species. Frontiers in Ecology and the Environment 18: 194-202.

Lavery JM, Kurek J, Rühland KM, Gillis CA, Pisaric MFJ, Smol JP. 2014. Exploring the environmental context of recent Didymosphenia geminata proliferation in Gaspésie, Quebec, using paleolimnology. Canadian Journal of Fisheries and Aquatic Sciences 71: 616-626.

Leung B, Lodge DM, Finnoff D, Shogren JF, Lewis MA, Lamberti G. 2002. An ounce of prevention or a pound of cure: Bioeconomic risk analysis of invasive species. Proceedings of the Royal Society B 269: 2407-2413.
Lockwood JL, Hoopes MF, Marchetti MP. 2007. Invasion Ecology. Wiley-Blackwell.

Loebl M, Van Beusekom JEE, Reise K. 2006. Is spread of the neophyte Spartina anglica recently enhanced by increasing temperatures? Aquatic Ecology 40: 315-324.

Low T. 2002. Why are there so few weeds? Pages 1-6 in Spafford Jacob $\mathrm{H}$, Dodd J, Moore JH eds. Proceedings of the $13^{\text {th }}$ Australian Weeds Conference. Plant Protection Society of of Western Australia.

Mack RN, Simberloff D, Lonsdale WM, Evans H, Clout M, Bazzaz FA. 2000. Biotic invasions: Causes, epidemiology, global consequences, and control. Ecological Applications 10: 689-710.

Magurran AE. 2009. Threats to freshwater fish. Science 325: 1215-1216.

Magurran AE, Baillie SR, Buckland ST, Dick JMP, Elston DA, Scott EM, Smith RI, Somerfield PJ, Watt AD. 2010. Long-term data sets in biodiversity research and monitoring: Assessing change in ecological communities through time. Trends in Ecology and Evolution 25: 574-582.

Magurran AE, Henderson PA. 2011. Commonness and rarity. Pages 97-104 in McGill BJ, Magurran A, eds. Biological Diversity Frontiers in Measurement and Assessment. Oxford University Press.

May RM. 1977. Thresholds and breakpoints in ecosystems with a multiplicity of stable states. Nature 269: 471-477.

McGill BJ, et al. 2007. Species abundance distributions: Moving beyond single prediction theories to integration within an ecological framework. Ecology Letters 10: 995-1015.

Mergeay J, Verschuren D, De Meester L. 2006. Invasion of an asexual American water flea clone throughout Africa and rapid displacement of a native sibling species. Proceedings of the Royal Society B 273: 2839-2844.

Mooney HA, Cleland EE. 2001. The evolutionary impact of invasive species. Proceedings of the National Academy of Sciences 98: 5446-5451.

Myers J. 2018. Invasive shrimp found in Twin Ports harbor. Duluth News Tribune (17 June 2020).

Nadel H, Frank JH, Knight RJ. 1992. Escapees and Accomplices: The naturalization of exotic ficus and their associated faunas in Florida. Florida Entomologist 75: 29-38.

Nehls G, Diederich S, Thieltges DW, Strasser M. 2006. Wadden Sea mussel beds invaded by oysters and slipper limpets: Competition or climate control? Helgoland Marine Research 60: 135-143.

Nuñez MA, Horton TR, Simberloff D. 2009. Lack of belowground mutualisms hinders Pinaceae invasions. Ecology 90: 2352-2359.

Papadopoulos NT, Plant RE, Carey JR. 2013. From trickle to flood: The large-scale, cryptic invasion of California by tropical fruit flies. Proceedings of the Royal Society B 280: 20131466.

Parker MA. 2001. Mutualism as a constraint on invasion success for legumes and rhizobia. Diversity and Distributions 7: 125-136.

Preston FW. 1948. The Commonness, And Rarity, of Species. Ecology 29: 254-283.

Provan J, Booth D, Todd NP, Beatty GE, Maggs CA. 2008. Tracking biological invasions in space and time: Elucidating the invasive history of the green alga Codium fragile using old DNA. Diversity and Distributions 14: 343-354.

Rabinowitz D. 1981. Seven forms of Rarity. Pages 205-217 in Synge H, ed. The Biological Aspects of Rare Plant Conservation. Wiley.

Rahmstorf S, Coumou D. 2011. Increase of extreme events in a warming world. Proceedings of the National Academy of Sciences 108: 17905-17909.

Ratajczak Z, Carpenter SR, Ives AR, Kucharik CJ, Ramiadantsoa T, Stegner MA, Williams JW, Zhang J, Turner MG. 2018. Abrupt change in ecological systems: Inference and diagnosis. Trends in Ecology and Evolution 33: $513-526$.

Rees HC, Maddison BC, Middleditch DJ, Patmore JRM, Gough KC. 2014. The detection of aquatic animal species using environmental DNA: A review of eDNA as a survey tool in ecology. Journal of Applied Ecology 51: 1450-1459.

Richardson DM, Allsopp N, D’Antonio CM, Milton SJ, Rejmanek M. 2000. Plant invasions: The role of mutualism. Biological Review 75: $65-93$. 
Rodríguez-Echeverría S, Fajardo S, Ruiz-Díez B, Fernández-Pascual M. 2012. Differential effectiveness of novel and old legume-rhizobia mutualisms: Implications for invasion by exotic legumes. Oecologia 170: 253-261.

Rothlisberger JD, Lodge DM. 2011. Limitations of gravity models in predicting the spread of Eurasian watermilfoil. Conservatoin Biology 25: 64-72.

Rouget M, Robertson MP, Wilson JRU, Hui C, Essl F, Renteria JL, Richardson DM. 2016. Invasion debt: Auantifying future biological invasions. Diversity and Distributions 22: 445-456.

Saunders MI, Metaxas A, Filgueiraa R. 2010. Implications of warming temperatures for population outbreaks of a nonindigenous species (Membranipora membranacea, Bryozoa) in rocky subtidal ecosystems. Limnology and Oceanography 55: 1627-1642.

Scheffer M, Carpenter SR. 2003. Catastrophic regime shifts in ecosystems: Linking theory to observation. Trends in Ecology and Evolution 18: 648-656.

Seebens H, et al. 2017. No saturation in the accumulation of alien species worldwide. Nature Communications 8: 1-9.

Shackleton RT, Biggs R, Richardson DM, Larson BMH. 2018. Social-ecological drivers and impacts of invasion-related regime shifts: Consequences for ecosystem services and human wellbeing. Environmental Science and Policy 89: 300-314.

Simberloff D, Von Holle B. 1999. Positive interactions of nonindigenous species: Invasional meltdown? Biological Invasions 1: 21-32.

Simberloff D, Souza L, Nũnez MA, Barrios-Garcia MN, Bunn W. 2012. The natives are restless, but not often and mostly when disturbed. Ecology 93: 598-607.

Stager JC, Sporn LA, Johnson M, Regalado S. 2015. Of paleo-genes and perch: What if an "alien" is actually a native? PLOS ONE 10: e0119071.

Stokes KE, Buckley YM, Sheppard AW. 2006. A modelling approach to estimate the effect of exotic pollinators on exotic weed population dynamics: Bumblebees and broom in Australia. Diversity and Distributions 12: $593-600$.

Stout JC, Kells AR, Goulson D. 2002. Pollination of the invasive exotic shrub Lupinus arboreus (Fabaceae) by introduced bees in Tasmania. Biological Conservation 106: 425-434.

Takahara T, Minamoto T, Doi H. 2013. Using environmental DNA to estimate the distribution of an invasive fish species in ponds. PLOS ONE 8: e56584.

Taylor BW, Bothwell ML. 2014. The origin of invasive microorganisms matters for science, policy, and management: The case of Didymosphenia geminata. BioScience 64: 531-538.

Taylor CM, Hastings A. 2005. Allee effects in biological invasions. Ecology Letters 8: 895-908.

Trapp RJ, Diffenbaugh NS, Brooks HE, Baldwin ME, Robinson ED, Pal JS. 2007. Changes in severe thunderstorm environment frequency during the 21st century caused by anthropogenically enhanced global radiative forcing. Proceedings of the National Academy of Sciences 104: 19719-19723.

US Fish and Wildlife Service. 2018. Invasive water flea found in Upper Mississippi River. US Fish and Wildlife Service Newsroom.

Vander Zanden MJ, Olden JD. 2008. A management framework for preventing the secondary spread of aquatic invasive species. Canadian Journal of Fisheries and Aquatic Sciences 65: 1512-1522.
Vander Zanden MJ, Hansen GJA, Higgins SN, Kornis MS. 2010. A pound of prevention, plus a pound of cure: Early detection and eradication of invasive species in the Laurentian Great Lakes. Journal of Great Lakes Research 36: 199-205.

Vander Zanden MJ, Hansen GJA, Latzka A. 2017. A framework for evaluating heterogeneity and landscape-level impacts of non-native aquatic species. Ecosystems 20: 477-491.

Vasseur DA, DeLong JP, Gilbert B, Greig HS, Harley CDG, McCann KS, Savage V, Tunney TD, O'Connor MI. 2014. Increased temperature variation poses a greater risk to species than climate warming. Proceedings of the Royal Society B 281: 20132612.

Vaughan RE, Wiehe PO. 1939. Studies on the vegetation of Mauritius: II. The effect of environment on certain features of leaf structure. Journal of Ecology 27: 263-281.

Vermeij GJ, Grosberg RK. 2018. Rarity and persistence. Ecology Letters 21:3-8.

Walsh JR, Carpenter SR, Vander Zanden MJ. 2016a. Invasive species triggers a massive loss of ecosystem services through a trophic cascade. Proceedings of the National Academy of Sciences 113: 201600366.

Walsh JR, Munoz S, Vander Zanden MJ. 2016b. Outbreak of an undetected invasive species triggered by a climate anomaly. Ecosphere 113: 4081-4085.

Walsh JR, Lathrop RC, Vander Zanden MJ. 2017. Invasive invertebrate predator, Bythotrephes longimanus, reverses trophic cascade in a northtemperate lake. Limnology and Oceanography 62: 2498-2509.

Walsh JR, Pedersen EJ, Vander Zanden MJ. 2018. Detecting species at low densities: A new theoretical framework and an empirical test on an invasive zooplankton. Ecosphere 9: e02475.

Williamson M, Fitter A. 1996. The varying success of invaders. Ecology 77: 1661-1666.

Wilson JRU, Dormontt EE, Prentis PJ, Lowe AJ, Richardson DM. 2009. Something in the way you move: Dispersal pathways affect invasion success. Trends in Ecology and Evolution 24: 136-144.

Witte S, Buschbaum C, van Beusekom JEE, Reise K. 2010. Does climatic warming explain why an introduced barnacle finally takes over after a lag of more than 50 years? Biological Invasions 12: 3579-3589.

Yan ND, Leung B, Lewis MA, Peacor SD. 2011. The spread, establishment and impacts of the spiny water flea, Bythotrephes longimanus, in temperate North America: A synopsis of the special issue. Biological Invasions 13: 2423 .

Michael J. Spear is a graduate student with the Center for Limnology at the University of Wisconsin-Madison, in Madison, Wisconsin, in the United States. Jake R. Walsh was a postdoctoral researcher with the Department of Fisheries, Wildlife, and Conservation Biology at the University of MinnesotaTwin Cities, in St. Paul, Minnesota, at the time of this work, and is now the invasive species grants and research coordinator for the Ecological and Water Resources Division of the Minnesota Department of Natural Resources, in St. Paul, Minnesota, in the United States. Anthony Ricciardi is a professor at the Redpath Museum and McGill School of Environment, at McGill University, in Montreal, Quebec, Canada, and is a research associate at the Centre for Invasion Biology at Stellenbosch University, in Stellenbosch, South Africa. M. Jake Vander Zanden is a professor and the director of the Center for Limnology at the University of Wisconsin-Madison, in Madison, Wisconsin, in the United States. 